\title{
Vampire Bat (Desmodus Rotundus) Abundancy and Frequency of Attacks to Cattle in Landscapes of Yucatan, Mexico
}

\section{Wendy Susana Sánchez-Gómez}

Universidad Autonoma de Yucatan Facultad de Medicina Veterinaria y Zootecnia

CELIA ISELA SELEM-SALAS ( $\sim$ ssalas@correo.uady.mx )

Universidad Autonoma de Yucatan Facultad de Medicina Veterinaria y Zootecnia

https://orcid.org/0000-0001-6445-7710

\section{Daniel Isaías Córdova-Aldana}

Comité Estatal de Fomento y Protección Pecuaria de Yucatan

José Alberto Erales-Villamil

Universidad Autonoma de Yucatan Facultad de Medicina Veterinaria y Zootecnia

\section{Research Article}

Keywords: abundancy, cattle, vampire bat, rabies, Yucatan, Mexico.

Posted Date: July 12th, 2021

DOl: https://doi.org/10.21203/rs.3.rs-639802/v1

License: (9) This work is licensed under a Creative Commons Attribution 4.0 International License.

Read Full License 


\section{Abstract}

Desmodus rotundus is one of the wild animal species that has benefitted by habitat alteration and its population has increased due to livestock activities. Because vampire bats have caused economic losses to livestock production by feeding from these and other mammals and being the main rabies virus transmitter for cattle, population control campaigns have been implemented in Mexico.

Yucatan is one of the seven most impacted States in Mexico by the number of cattle rabies cases per year, however, there is little research on vampire bat populations and attacks to cattle frequency patterns has never been analyzed so far.

This study's objective was to analyze the relationship between $D$. rotundus abundancy and number of bovines attacked in livestock landscapes in Yucatan. The study used data gathered by the State Committee for Protection and Promotion of Livestock in Yucatan through the National Campaign for Vampire Bat Population Control. Data from January 2014 to December 2017 was analyzed using Pearson correlation and bat abundancy and number of bovines attacked distribution maps. Greater abundancy of vampire bats and number of cattle attacked were observed in the central region of Yucatan, particularly in Izamal municipality. Positive correlation was found between 1) Abundancy of vampire bats and number of cattle in the region, 2) Total number of cattle and number of cattle attacked, and 3) Abundancy of vampire bats and number of cattle attacked. We can conclude that the relationship between abundancy of vampire bats and frequency of cattle attacked is positive.

\section{Introduction}

It has been proved that anthropogenic activities affect the dynamic and distribution of wild animal populations (Wiens, 1989; Zarco et al., 2012). Despite most of the time these effects are negative for the wild animal species (Di Bitetti et al., 2013; Martinuzzi et al., 2015), vampire bat populations have been favored from one of the main uses of land in Latin America, livestock production (Fenton et al., 1992; Garcia-Morales et al., 2013). Out of the three species of vampire bats in Latina America, Desmodus rotundus is the only one that feeds from mammals (Kunz y Fenton, 2003; Mayen, 2003; Kraker-Castañeda y Echeverría-Tello, 2012), and although in less fragmented areas, Desmodus still feeds from wild populations of peccary and deer (Belwood y Morton, 2014; Galetti et al., 2016), abundance and accessibility to livestock has made of cattle, its main source of feed (Voigt y Kelm, 2006; Mialhe, 2014; Bobrowiec et al., 2015). Among livestock, cattle are preferred by vampire bats (Anderson, A. et al., 2012; Johnson et al., 2014), frequently selecting young, weak or individuals resting at the limits of the herd (Greenhall, 1988; Delpietro et al., 1992; Bobrowiec 2012). Along its distribution, from Sonora, Mexico to the North of Argentina (Reid, 1997; Hayes y Piaggio, 2018; Osorio y Saldaña, 2019), D. rotundus has caused economic loses because it is the main rabies virus transmitter (Dantas-Torres et al., 2005; Reis et al., 2007). Annual loses for over 30 million USD has been estimated in Latin America alone (Blackwood et al., 2013), and particularly in Mexico, annual loses for over 2.6 million USD (Zarza et al., 2017) have been estimated. To reduce this economic loses, in Mexico since 1968, the National Institute for Agriculture, 
Forestry and Livestock Research (INIFAP) established a program to control and prevent rabies disease in livestock which also included vampire bat population control and annual anti rabies vaccination to livestock averaging 5.8 million vaccines every year (SAGARPA, 2009). Despite partial and temporal vampire bat population control, and reduction of cattle rabies cases achieved through this program, vampire bat populations recover with no difficulty (Streicker et al., 2012, Rocha et al., 2020) and livestock attacks continue to occur year long, compromising health and productivity of livestock (Johnson y Montaño, 2018). Besides factors such as landscape structure, refuge availability and climatic conditions, livestock abundance can determine vampire bat abundancy in a region (Rocha y Días, 2020; Bobrowiec et al., 2015; Zarza et al., 2017; Bolívar-Cimé et al., 2019; Rocha et al., 2020), being associated even with demographic aspects of the colony (Becker et al., 2018). Under these circumstances, regions with livestock abundance will also have bigger vampire bat populations, a greater number of cattle would be attacked and thus a bigger probability of rabies presentation in cattle would be expected. Despite Yucatan does not have the biggest cattle production in Mexico, Epidemiological surveillance campaigns suggest that is one of the seven States of Mexico affected with more rabies cases in cattle, having between 1997 and 2016, 5,653 cases in cattle (Senasica, 2018). Nevertheless, there are few studies aimed to understand vampire bat populations and to monitor cattle attacks. Vampire bat abundance and frequency of cattle attacked analysis, could contribute to improve population control plans and strategies to vaccinate cattle in Yucatan State. This study's objective is to estimate Desmodus rotundus abundance and number of cattle attacked, and to analyze the relationship between them in livestock landscapes in Yucatan, Mexico.

\section{Methods}

\section{Study area}

Yucatan has warm subhumid climate with rains from June to October and a dry season from November to April (Estrada Medina et al., 2016). Average annual rain is around $1100 \mathrm{~mm}$, and mean temperature is $26^{\circ} \mathrm{C}$ (INEGI, 2017). Dominant vegetation is deciduous jungle (Flores et al., 2010) covering more than $73.5 \%$ of Yucatan area, whereas $17.3 \%$ is cover by grasslands (INEGI, 2017). Geographically, Yucatan has nine regions, East Coast (Region 1) East (Region 2) Central Coast (Region 3) Central (Region 4) Central South (Region 5) Metropolitan influence (Region 6) West Coast (Region 7) West South (Region 8) and South (Region 9) (INEGI, 2011). Municipalities with the largest number of cattle heads are Tizimin, Buctzotz, Panaba y Sucila (INEGI, 2007).

\section{Data Gathering}

This study used data gather by the national campaign for vampire bat population control operated by the State Committee for protection and promotion of livestock in Yucatan (CEFPPY). Data from Livestock Production Units (UPP's) visits, from January 2014 to December 2017, was used. The number of municipalities and UPP's visited per year were different every year due to farmer request for population 
control activities, prioritizing places where rabies cases were confirmed by laboratory tests and visiting UPP's located within a radius of $10 \mathrm{~km}$ from where the confirmed case was located.

Three nights before vampire bat capture, CEFPPY asked farmers to lock their animals in their pens overnight, where the vampire bats were to be captured, since $D$. rotundus tends to get familiar to where the animals are located (Piccinini et al., 1985). Before the capture, number of animals in the pen was recorded and the number of animals that presented at least one vampire bat bite. Fog nets $2.10 \mathrm{~m}$ high and 6, 9 or $12 \mathrm{~m}$ long were placed, surrounding the pen (number of nets varied according to size of the pen) and were kept open for at least 7 hours.

\section{Data Analysis}

Estimates of 1) vampire bat abundancy 2) number of cattle heads 3) number of cattle heads attacked by bats 4) proportion cattle heads attacked by municipality and year. To learn about the effect of year for "vampire bat abundancy" and "number of cattle heads attacked" ANOVA and Tukey tests were performed. Maps of distribution for vampire bat abundancy and number of cattle heads attacked from January 2014 to December 2017. Pearson's correlation matrix was created to identify relationships among those four variables. For Analysis and Maps creation, software R version 3.63 was used.

\section{Results}

\section{Municipalities, UPP's, and Number of Visits}

Data from 79 municipalities (2014: 38, 2015: 63, 2016: 39, 2017: 36); 1,259 visits (2014: 303, 2015: 466, 2016: 261, 2017: 229) and 1,229 UPP's were analyzed. Number of UPP's and Number of visits were the same since UPP's were only visited once per year. Municipalities with greatest number of visits were Tzucacab (105), Izamal (90), and Buctzotz (82), whereas Abala, Acanceh, Kaua, Progreso, Samahil, San Felipe, Seye, Teabo, Ucu, and Yobain were visited only once.

\section{Vampire bat abundancy}

9,185 vampire bats were captured, having the greatest number of vampire bats captured in 2015 and the smallest number captured on 2014 (Table \#1). On average, 2,296 vampire bats were captured every year, 116 per municipality and 7 per UPP. Similarly to Costa and Esberard (2011) findings; municipalities with greater number of visits had greater abundancy, except Tizimin municipality, which ranks 5 th on number of visits and 140 individuals were captured, and Yaxcaba, where 218 bats were captured in 4 visits. MacSwiney et al., (2007) suggested that $D$. rotundus is the second most abundant species in Cenotes located on grazing paddocks from livestock landscapes in Yucatan and, according to Ruiz et al., (2007), the Cenotes are the refugia for $85 \%$ of bats in Yucatan, finding most of cenotes in the Eastern Coastal and Eastern region of the Yucatan State. Nevertheless, in our study, Municipalities that registered the greatest number of vampire bats were Izamal (1.255), Sudzal (715), Buctzotz (673), and Tunkas (621) (Fig. 1), which are in the Central region of Yucatan, except for Buctzotz, which is located in the Eastern Coastal region. Smallest abundancies were found in Progreso (1) and Yobain (1), both located in the 
Coastal region of Yucatan. Municipalities with greatest and smallest number of individuals per year are shown in Table 1.

Despite Tizimin municipality and in general terms, the Eastern region of Yucatan have a greater proportion of cattle and cave-like cenotes, than other regions (INEGI, 2007; Anderson, S. et al, 2012; Ruiz Silva, 2007), according to our findings, Izamal municipality and surrounding municipalities in the Central region, have a greater abundance of vampire bats. In addition, Izamal, registered the greatest number of cattle attacked for years 2016 and 2017 and in general, for the full observation period. It is suggested that in Yucatan there are from 7,000 to 8,000 cenotes, however, there are still some cenotes and caves not registered, therefore refugia availability (cave-like cenotes) in Central region for vampire bats might be greater than expected, not considering availability of other refugia either natural or artificial. In addition, factors such as distance from refugia to night resting area for preys, density of cattle, and level of human interference, might play an important role in vampire bat abundancy and incidence of cattle attacks (Andrade et al., 2015; Orlando et al., 2019; Lanzagorta et al., 2020) therefore, behavior of these variables per municipality and UPP, besides cattle abundancy and availability of refugia need to be analyzed.

\section{Attacks to cattle}

In Yucatan, 37,019 head of cattle were inspected, 5,450 presented at least, one bat's bite, representing $14.72 \%$ of total cattle inspected, whereas in Ecuador, Orlando et al., (2019) reported 23.3\% of 1,195 cattle to be attacked by vampire bats. Our results suggest that, on average, 4 head of cattle are attacked every night, considering 79 municipalities with 1,229 UPP and 4 years of observations. In terms of head of cattle attacked by municipality during the full observation period, Izamal (509), Tzucacab (467), Tunkas (456), and Sudzal (376) presented highest number of head of cattle attacked, whereas Progreso (1), San Felipe, Santa Elena and Ucu (2) presented the lowest records (Figure \#2). Even though the greatest number of cattle is found in the northeast region of Yucatan (INEGI, 2007), in this study, the greatest number of cattle attacked was in the central region of the State. This is consistent with the study done by Moya et al., (2015) in Bolivia, where they found that the largest incidence of cattle attacks was not observed in the locations with the largest number of cattle.

Excluding municipalities where only one head of cattle was recorded and it was attacked, the greatest proportion of cattle attacked was recorded in Suma $(2014,6 / 10)$, Yaxcaba $(2015,38 / 38 ; 2016,60 / 60)$ and Kinchil $(2017,16 / 16)$. During the full observation period, Kaua, Yaxcaba and Seye presented the greatest percentage of cattle attacked $(100 \%, 100 \%$, and $59 \%$ respectively). It is important to mention that in these municipalities, the number of cattle was small, similar to what Turner (1975) reported, who suggests that locations with less cattle, frequency of attacks is greater since vampire bats have to feed from the same individuals. In the same way, Moya et al (2015) found that in pens with less cattle, the incidence of attacks was higher. Moreover, it has been found that in less fragmented zones, where abundancy of wild animals is greater, incidence of attacks to cattle is smaller (Torres et al., 2014). On the other hand, Orlando et al (2019) suggest that vegetation could play an important role on the incidence of vampire bats attacks. Same authors (Orlando et al., 2019) found greater number of attacks in places with 
high vegetation index, and in a study in Sao Paulo, Brazil (Gomez et al., 2010), it was observed that as the distance from cattle to unfragmented woods and grazing areas decreases, the incidence of vampire bat attacks increases.

Table 1

Vampire bat and cattle abundancy and number of cattle attacked from Jan 2014 to December 2017.

\begin{tabular}{|lllll|}
\hline Variable & $\mathbf{2 0 1 4}$ & $\mathbf{2 0 1 5}$ & $\mathbf{2 0 1 6}$ & $\mathbf{2 0 1 7}$ \\
\hline CATTLE POPULATION & 8,854 & $\mathbf{1 2 , 0 5 9}$ & 9,314 & 6,792 \\
\hline NUMBER OF CATTLE ATTACKED & 1,093 & $\mathbf{1 , 7 6 8}$ & 1,578 & 1,011 \\
\hline PROPORTION OF CATTLE ATTACKED & $21.1 \%$ & $20.0 \%$ & $\mathbf{2 1 . 5 \%}$ & $20.5 \%$ \\
\hline VAMPIRE BAT ABUNDANCY & 1,667 & $\mathbf{2 , 8 1 9}$ & 2,605 & 2,094 \\
\hline
\end{tabular}

Table 2

Municipalities with greatest and smallest number of vampire bats and cattle attacked per year. $\mathbf{T}=$ Total, A $=$ Attacked

\begin{tabular}{|c|c|c|c|c|}
\hline Year & $\begin{array}{l}\text { Municipality with } \\
>n^{\circ} \text { of vampire } \\
\text { bats }\end{array}$ & $\begin{array}{l}\text { Municipality with } \\
<n^{0} \text { of vampire } \\
\text { bats. }\end{array}$ & $\begin{array}{l}\text { Municipality with > } \\
n^{\circ} \text { of cattle } \\
\text { attacked }\end{array}$ & $\begin{array}{l}\text { Municipality with }<n^{\circ} \text { of } \\
\text { cattle attacked }\end{array}$ \\
\hline 2014 & Sudzal (212) & $\begin{array}{l}\text { Cansahcab (1), } \\
\text { Kopomá (1) }\end{array}$ & $\begin{array}{l}\text { Tzucacab (T: 714, } \\
\text { A: 109) }\end{array}$ & $\begin{array}{l}\text { Cansahcab (T: 1, A: 1), } \\
\text { Kopomá (T: 30, A: 1) }\end{array}$ \\
\hline 2015 & Buctzotz (282) & $\begin{array}{l}\text { Progreso (1), } \\
\text { Yobaín (1) }\end{array}$ & $\begin{array}{l}\text { Sudzal (T: 390, A: } \\
\text { 184) }\end{array}$ & $\begin{array}{l}\text { Baca (T: 23, A: 1), } \\
\text { Dzilam González (T: 19, } \\
\text { A: 1), Progreso (T: 240, A: } \\
\text { 1) }\end{array}$ \\
\hline 2016 & Izamal (363) & Cacalchen (1) & $\begin{array}{l}\text { Tunkás (T: 856, A: } \\
\text { 218) }\end{array}$ & $\begin{array}{l}\text { Cacalchén (T: 22, A: 1), } \\
\text { Kantunil (T: 64, A: 1), } \\
\text { Muna (T: 12, A: 1) }\end{array}$ \\
\hline 2017 & Izamal (666) & Muna (2) & $\begin{array}{l}\text { Izamal (T: 1042, A: } \\
261)\end{array}$ & Dzemul (T: 7, A: 1) \\
\hline
\end{tabular}

\section{ANOVA AND CORRELATION ANALYSIS}

Despite some studies suggest annual changes in vampire bat abundancy (Costa and Esberard, 2011), according to our results of ANOVA and Tukey tests, there is no statistical effect of "year" as a factor for 
the variables analyzed (Fig. 3), similar to Rocha and Dias (2020) observations, who did not find differences in vampire bats captured in consecutive years.

High positive correlation was found between vampire bats captured and number of cattle heads attacked (Fig. 4), which corresponds with Moya et al., (2015) study, who observed that in places with high vampire bat abundancy, the incidence of attacks was higher. In addition, a positive correlation between total cattle and number of vampire bats captured (Fig. 4) was found. This coincides with Becker et al., (2018) findings. Past studies (Schmidt et al., 1971; Turner, 1975) suggest that incidence of attacks is not related to abundancy of mammal preys, however, our work suggests a positive relation between total number of cattle and the number of cattle attacked (Fig. 4), similarly, Orlando et al., (2019) found a correlation between number of cattle attacked and herd size, and between number of bites and number of cattle attacked.

\section{Discussion}

This is the first study in Yucatan that provides information about D. rotundus abundancy, and the number of cattle attacked per municipality at a state level. Despite lack of data from places where no report on rabies cases is done, this work presents the first approach to understand the populations of vampire bats per municipality and state level. Number of visits were not equal per municipality, since visits vary according to the UPP owner requests, prioritizing visits towards Rabies confirmed cases, in which case, number of visits is already a self-explaining variable of level of disease (or level of cattle attacks) in every municipality.

Results suggest paying more attention to Central region and vampire bat populations. Despite Izamal municipality is not recognized for a large cattle activity, (INEGI, 2007), Izamal registered the greatest number of vampire bats and greatest number of cattle attacked, supporting the need to constantly monitor vampire bat populations and study patterns in the frequency of cattle attacks.

To establish and understand predictive patterns of vampire bat attacks to cattle, is necessary to analyze, besides abundancy, the behavior of other variables such as 1) distance from cattle resting pens to refugia; 2) distance from cattle night rest pens to human influence area (roads, households, night lights, etc.);3) Vegetation density around cattle night resting area; 4) abundancy of wild species used as preys. It is also suggested, to study at regional level, or smaller level studies, as proposed by Gomez et al., (2007), to obtain more detailed information. Outcomes from such studies may help re orient vaccination strategies or population control measures for $D$. rotundus that might vary from one region to other. According to Moya et al., (2015), limiting factor in cattle attack incidence for vampire bats is not cattle abundancy, but refugia availability, therefore, Yucatan even though does not present high inventory of cattle (INEGI, 2007), probably due to its topography, offers high availability of refugia (cenotes and caves) for vampire bats, favoring population growth and increasing the problem of cattle attacks and rabies in Yucatan. 
Even though our results may be limited by the number of times UPP's were visited, since these visits were done per request by the UPP's owner, we can conclude that 1) abundancy of vampire bats and number of head of cattle attacked are similar form year to year. 2) in the central region of Yucatan, particularly Izamal municipality, vampire bats and head of cattle attacked seem to be higher than other regions of Yucatan State. We suggest that further studies in the central region of Yucatan are needed to analyze, besides abundancy of cattle, other variables that might play a role in the frequency of vampire bat attacks, particularly those related to abundancy and/or availability of refugia.

\section{Declarations}

\section{ACKNOWLEDGEMENTS}

The authors thanks State Committee for Protection and Promotion of Livestock by provided the data for this study. Special thanks to MVZ. Edwin Novelo Ayuso, MVZ. Franklin José Quiñones Ávila, Mr. Jorge Puerto Cabrera and Dr. José Alejandro Jiménez Ramírez.

\section{Data availability}

The datasets analysed during the current study are available from the corresponding author on reasonable request.

\section{Conflict of interest}

The authors declare that they have no conflict of interest.

\section{Funding}

The data collection used on the present study was financed by the National Service of Agrifood Health, Safety and Quality (SENASICA).

\section{AUTHOR INFORMATION}

\section{Contributions}

WSSG, CISS and JAEV conceived this study. DICA collected data. WSSG, CISS and JAEV analized data. WSSG wrote the first version of the manuscript. CISS and JAEV revised and edited final version of the manuscript.

\section{References}

1. Anderson, A., Scwiff, S., Gebhardt, K., Ramírez, A. J., Kohler, D., Lecuona, L. 2012. Economic evaluation of vampire bat (Desmodus rotundus) rabies prevention in Mexico. Transboundary and Emerging Diseases, 61, 140-146. doi:10.1111/tbed.12007 
2. Anderson, S., Santos, J., Boden, R., Wadsworth, J., 2012. Characterization of Cattle Production Systems in the State of Yucatan. Dual Purpose Cattle Production Research. México. Fundación Internacional para la Ciencia, 40(2), 187-192.

3. Andrade, F. A., França, É. S., Souza, V. P., Barreto, M. S., Fernandes, M. E. 2015. Spatial and temporal analysis of attacks by common vampire bats (Desmodus rotundus) on humans in the rural Brazilian Amazon basin. Acta Chiropterologica, 17(2), 393-400.

4. Becker, D. J., Czirják, G. Á., Volokhov, D. V., Bentz, A. B., Carrera, J. E., Camus M. S., et al. 2018. Livestock abundance predicts vampire bat demography, immune profiles and bacterial infection risk. Philosophical Transactions of the Royal Society B: Biological Sciences, 373, 20170089. DOI: 10.1098/rstb.2017.0089

5. Beddows, P., Blanchon, P., Escobar, E., Torres-Talamante, O. 2007. Los cenotes de la Península de Yucatán. Arqueología Mexicana, 14(5), 32-35.

6. Belwood, J. J., Morton, P. A. 2014. Vampires: the real story. Viruses, 6, 1911-1928.

7. Blackwood, J. C., Streicker, D. G., Altizer, S., Rohani, P. 2013. Resolving the roles of immunity, pathogenesis, and immigration for rabies persistence in vampire bats. Proceedings of the National Academy of Sciences of the United States of America, 110, 20837-20842. https://doi.org/10.1073/pnas.1308817110

8. Bobrowiec, P. E. D. 2012. A chiroptera preliminary survey in the middle Madeira River region of Central Amazonia, Brazil. Mammalia, 76, 277-283. https://doi.org/10.1515/mammalia-2011-0065

9. Bobrowiec, P. E. D., Lemes, M. R., Gribel, R. 2015. Prey preference of the common vampire bat (Desmodus rotundus, Chiroptera) using molecular analysis. Journal of Mammalogy, 96(1), 54-63. DOl:10.1093/jmammal/gyu002

10. Bolívar-Cime, B., Flores-Peredo, R., García-Ortiz, S. A., Murrieta-Galindo, R., Laborde, J. 2019. Influence of landscape structure on the abundance of Desmodus rotundus (Geoffroy 1810) in northeastern Yucatan, Mexico. Ecosistemas y Recursos Agropecuarios, 6(17), 263-271.

11. Cao, C., Lam, N. 1997. Understanding the scale and resolution effects inremote sensing and GIS. In: Quattrochi D.A., Goodchild, M. F. ed. Scale in Remote Sensing and GIS. CRC Lewis, Boca Raton. Pp. 57-72.

12. Costa, L. M., Esbérard, C. E. L. 2011. Desmodus rotundus (Mammalia: Chiroptera) on the southern coast of Rio de Janeiro state, Brazil. Brazilian Journal Biology, 71, 1-8. doi: 10.1590/S151969842011000400020

13. Dantas-Torres, F., Valencia, C., de Andrade-Filho, G. 2005. First record of Desmodus rotundus in an urban area from the city of Olinda, Pernambuco, northeastern Brazil: a case report. Revista Institucional de Medicina Tropical de Sao Paulo, 47, 107-108.

14. De Azevedo, F., Murray, D. 2007. Evolution of potencial factors predisposing livestock to predation by jaguars. Journal of Wildlife Management, 71, 2379-2386.

15. Delpietro, H. A., Marchevsky, N., Simonetti, E. 1992. Relative population densities and predation of the common vampire bat (Desmodus rotundus) in natural and cattle-raising areas in northeast 
Argentina. Preventive Veterinary Medicine, 14, 13-20.

16. Di Bitetti, M. S., Albanesi, S. A., Foguet, M. J., De Angelo, C., Brown, A. D. 2013. The effect of anthropic pressures and elevation on the large and medium-sized terrestrial mammals of the subtropical mountain forests (Yungas) of NW Argentina. Mammalian Biology, 78, 21-27. https://doi.org/10.1016/j.mambio.2012.08.006

17. Estrada-Medina, H., Cobos-Gasca, V., Acosta-Rodríguez, J. L., Peña Fierro, S., Castilla-Martínez, M., Castillo-Carrillo, C., et al. 2016. La sequía de la península de Yucatán. Tecnología y ciencias del agua, 7(5), 151-165.

18. Fenton, M. B., Acharya, L., Audet, D., Hickey, M. B. C., Merriman, C., Obrist, M. K., et al. 1992. Phyllostomid bats (Chiroptera: Phyllostomidae) as indicators of habitat disruption in the Neotropics. Biotropica, 24(3), 440-446. https://doi.org/10.2307/2388615

19. Flores-Guido, J., Durán-García, R., Ortíz-Díaz, J. 2010. Comunidades vegetales terrestres. En: Durán, R., Méndez, M. eds. Biodiversidad y Desarrollo Humano en Yucatán. Centro de Investigaciones Científicas de Yucatán, Programa de Pequeñas Donaciones del Fondo para el Medio Ambiente Mundial, Comisión Nacional para el Conocimiento y Uso de la Biodiversidad, Secretaría de Desarrollo Urbano y Medio Ambiente del Gobierno del Estado de Yucatán. Mérida, México. Pp. 125-129.

20. Galetti, M., Pedrosa, F., Keuroghlian, A., Sazima, I. 2016. Liquid lunch-vampire bats feed on invasive feral pigs and other ungulates. Frontiers in Ecology and the Environment, 14(9), 505-506. https://doi.org/10.1002/fee.1431

21. García-Morales, R., Badano, E. I. y Moreno, C. E. 2013. Response of Neotropical bat assemblages to human land use. Conservation Biology, 27, 1096-1106. DOI: 10.1111/cobi.12099

22. Greenhall, A. M. 1988. Feeding behavior. In: Greenhall, A. M., Schmidt, U. eds. Natural history of vampire bats. CRC Press, Boca Raton, Florida. Pp. 111-131.

23. Gomes, M. N., Monteiro, A. M., Lewis, N., Goncalves, C. A., Filho, V. S. 2010. Landscape risk factors for attacks of vampire bats on cattle in Sao Paulo, Brazil. Preventive Veterinary Medicine, 93,139-146. doi: 10.1016/j.prevetmed.2009.10.006.

24. Hayes, M. A., Piaggio, A. J. 2018. Assessing the potential impacts of a changing climate on the distribution of a rabies virus vector. PLoS One, 13(2). https://doi.org/10.1371/journal.pone.0192887

25. INEGI. (Instituto Nacional de Estadística y Geografía). 2007. Dirección General de Estadísticas Económicas. Estados Unidos Mexicanos. VIII Censo Agrícola, Ganadero y Forestal. www.inegi.org.mx (Consultado el 15 de agosto de 2020).

26. INEGI (Instituto Nacional de Estadística y Geografía). 2017. Anuario estadístico y geográfico de Yucatán. 708 p. https://www.datatur.sectur.gob.mx/ITxEF_Docs/YUC_ANUARIO_PDF.pdf (Consultado el 20 de julio de 2020).

27. Johnson, N., Aréchiga-Ceballos, N., Aguilar-Setien, A. 2014. Vampire bat rabies: Ecology, epidemiology, and control. Viruses, 6, 1911-1928. doi:10.3390/v6051911

28. Johnson, N., y Montano, J. H. 2018. The impact of paralytic bovine rabies transmitted by vampire bats in Latin America and the Caribbean. Revue scientifique et technique (International Office of 
Epizootics), 37(2), 451-459. DOI: 10.20506/rst.37.2.2814

29. Kraker-Castañeda, C., Echeverría-Tello, J. L. 2012. Riqueza de especies y variabilidad trófica de murciélagos en zonas de riesgo de rabia de origen silvestre en Izabal, Guatemala. Therya, 3(1), 8799. DOI: $10.12933 /$ therya-12-57 I

30. Kunz, T., Fenton, B. 2003. Bat ecology. The University of Chicago Press, USA.

31. Lanzagorta-Valencia, K., Fernández-Méndez, J. I., Medellín, R. A., Rodas-Martínez, A. Z., Ávila-Flores, R. 2020. Landscape and cattle management attributes associated with the incidence of Desmodus rotundus attacks on cattle. Ecosistemas y Recursos Agropecuarios, 7(1), 1-10.

32. MacSwiney, M. C., Vilchis, P., Clarke, F. M., Racey, P. A. 2007. The importance of cenotes in conserving bat assemblages in the Yucatan, Mexico. Biological conservation, 136, 499-509.

33. Martinuzzi, S. N., Withey, J. C., Pidgeon, A. M., Plantinga, A. J., McKerrow, A. J., Williams, S. G., et al. 2015. Future land-use scenarios and the loss of wildlife habitats in the southeastern United States. Ecological Applications, 25, 160-171. doi: 10.1890/13-2078.1

34. Mayen, F. 2003. Haematophagous bats in Brazil, their role in rabies transmission, impact on public health, livestock industry and alternatives to an indiscriminate reduction of bat population. Journal of Veterinary Medicine, 50, 469-472. DOI: 10.1046/j.1439-0450.2003. 00713.x

35. Mialhe, P. J. 2014. Preferential prey selection by Desmodus rotundus (E. Geoffroy, 1810, Chiroptera, Phyllostomidae) feeding on domestic herbivores in the municipality of São Pedro - SP. Brazilian Journal of Biology, 74(3), 579-584. https://doi.org/10.1590/bjb.2014.0086

36. Orlando, S. A., Panchana, V. F., Calderón, J. L., Muñoz, O. S., Campos, D. N., Torres-Lasso, P. R., Quentin, E. 2019. Risk factors associated with attacks of hematophagous Bats (Desmodus rotundus) on cattle in ecuador. Vector-Borne and Zoonotic Diseases, 19(6), 407-413. DOI: $10.1089 / v b z .2017 .2247$

37. Osorio-Rodríguez, A. N., Saldaña-Vázquez, R. A. 2019. Control del murciélago vampiro común (Desmodus rotundus) en México: ¿Qué tan efectiva es para controlar la rabia bovina? En: OrnelasGarcía, C. P., Álvarez, F., Wegier, A. eds. Antropización: Primer Análisis Integral, 21, 403-411. CONACYT-IBUNAM.

38. Piccinini, R. S., Peracelli A. L, Souza, J. C. P., Albuquerque, S. T., Raimundo, S. D. L, Tannure, A. M., Furtado, L L. 1985. Comportamento do morcego hematófago Desmodus rotundus (Chiroptera) relacionado com a taxa de ataque a bovinos em cativeiro. Pesquisa Veterinária Brasileira, 5(4), 111116.

39. Reid, F. A. 1997. A field guide to the mammals of Central America and Southeast Mexico. New York: Oxford University Press.

40. Reis, N. R., Peracchi, A. L., Pedro, W. A., Lima, I. P. 2007. Morcegos do Brasil. Universidade Estadual de Londrina. Londrina, Paraná, Brazil.

41. Rocha, F., Dias, R. A. 2020. The common vampire bat Desmodus rotundus (Chiroptera: Phyllostomidae) and the transmission of the rabies virus to livestock: A contact network approach 
and recommendations for surveillance and control. Preventive Veterinary Medicine, 174. https://doi.org/10.1016/j.prevetmed.2019.104809

42. Rocha, F., Ulloa-Stanojlovic, F. M., Rabaquim, V. C. V., Fadil, P., Pompei, J. C., Brandão, P. E., Dias, R. A. 2020. Relations between topography, feeding sites, and foraging behavior of the vampire bat, Desmodus rotundus. Journal of Mammalogy, 101(1), 164-171. DOl:10.1093/jmammal/gyz177

43. Ruíz-Silva, J., Rivadeneyra, J., Pacheco-Sosa, A., Sosa-Escalante, J., Morales-Arjona, L. J. 2007. Caracterización de los cenotes y grutas del estado de Yucatán, México. Secretaría de Ecología, Gobierno del Estado de Yucatán. Mérida, México. 215 p.

44. SAGARPA (Secretaría de Agricultura, Ganadería, Desarrollo Rural, Pesca y Alimentación). 2009. Dirección general de salud animal. (Consultado el 15 de julio de 2020).

45. Schmidt, V. U., Greenhall, A. M., López-Forment, W. 1971. Ökologische Untersuchungen der Vampirfledermäuse (Desmodus rotundus) im Staate Puebla, Mexiko. Sonderdrucke aus Z. f. Sëugetierkunde Bd. 36, 6, 360-370.

46. SENASICA (Servicio Nacional de Sanidad, Inocuidad y Calidad Agroalimentaria). 2018. Dirección General de Salud Animal. Dirección de Campañas Zoosanitarias. https://www.gob.mx/senasica/documentos/programas-2018-direccion-general-de-salud-animal (Consultado el 28 de mayo de 2020).

47. Streicker, D. G., Recuenco, S., Valderrama, W., Benavides, J. G., Vargas, I., Pacheco, V., CondoriCondori, R. E., Montgomery, J., Rupprecht, C. E., Rohani, P., Altizer, S. 2012. Ecological and anthropogenic drivers of rabies exposure in vampire bats: implications for transmission and control. Proceedings of the Royal Society of London, B: Biological Sciences, 279, 3384-3392.

48. Torres, C., Lema, C., Dohmen, F.G., Beltran, F., Novaro, L., Russo, S., Freire, M.C., Velasco-Villa, A., Mbayed, V.A., Cisterna, D.M., 2014. Phylodynamics of vampire battransmitted rabies in Argentina. Molecular ecology, 23(9), 2340-2352. DOI:10,1111/mec.12728

49. Turner, D. C. 1975. The Vampire Bat: A field study in behavior and ecology. The John Hopkins University Press. Baltimore/London.

50. Voigt, C. C., Kelm, D. H. 2006. Host preference of the common vampire bat (Desmodus rotundus; Chiroptera) assessed by stable isotopes. Journal of Mammalogy, 87, 1-6.

51. Wiens, J. 1989. Spatial scaling in ecology. Functional ecology, 3(4), 385-397. DOI: 10.1007/s10745012-9505-4

52. Zarco-González, M. M., Monroy-Vilchis, O., Rodríguez-Soto, C., Urios, V. 2012. Spatial factors and management associated with livestock predations by Puma concolor in Central Mexico. Human Ecology, 40, 631-638. DOI 10.1007/s10745-012-9505-4

53. Zarza, H., Martínez-Meyer, E., Suzán, G., Ceballos, G. 2017. Geographic distribution of Desmodus rotundus in Mexico under current and future climate change scenarios: Implications for bovine paralytic rabies infection. Veterinaria México, 4(3), 1-16. http://dx.doi.org/10.21753/vmoa.4.3.390.

\section{Figures}




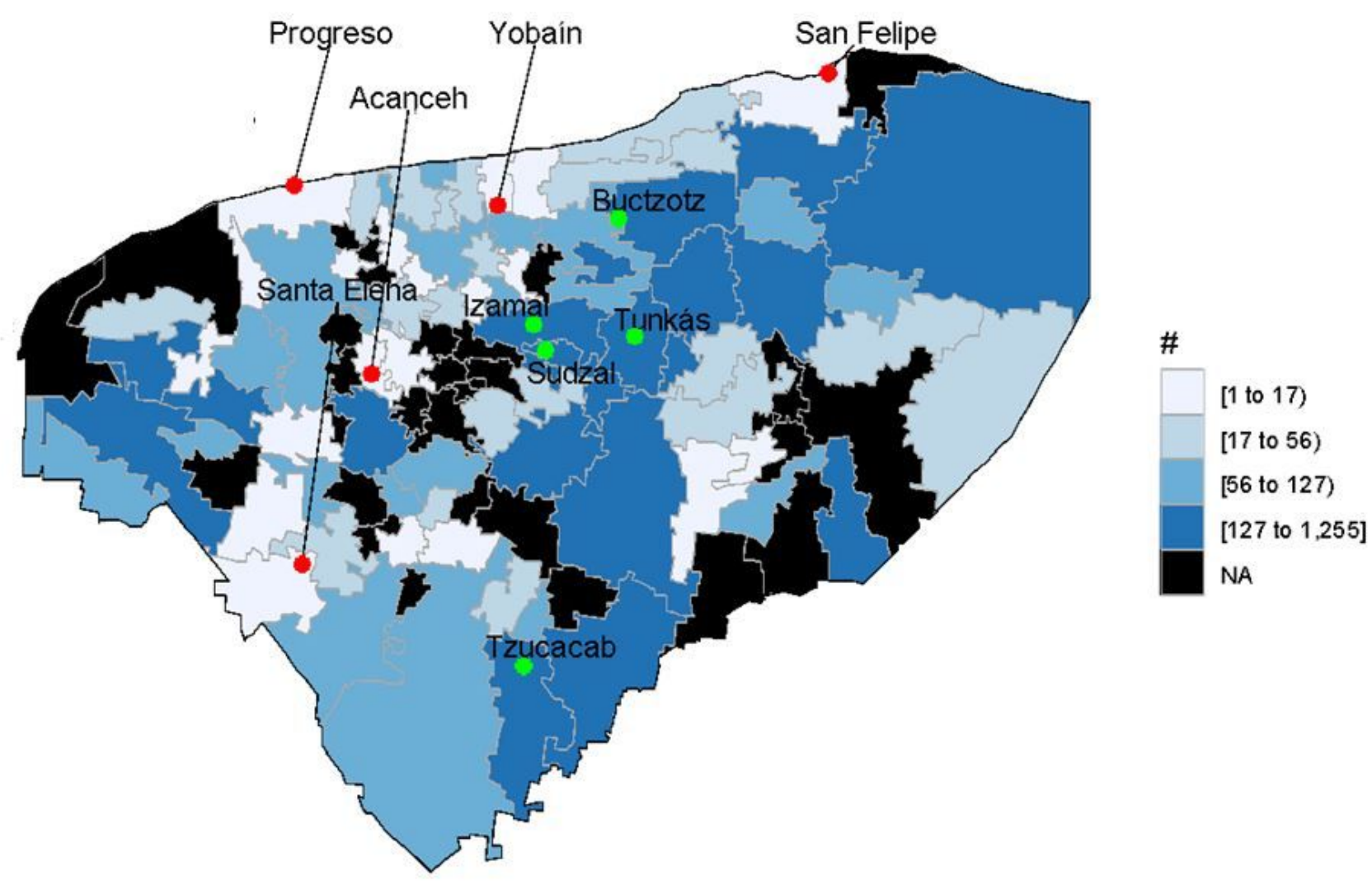

\section{Figure 1}

Number of vampire bat captures in Yucatán by municipality from 2014 to 2017 . Municipalities with greater number of bats captured are marked with green dots and municipalities with smaller number of bats captured are marked with red dots. NA: No captures performed in these municipalities. 


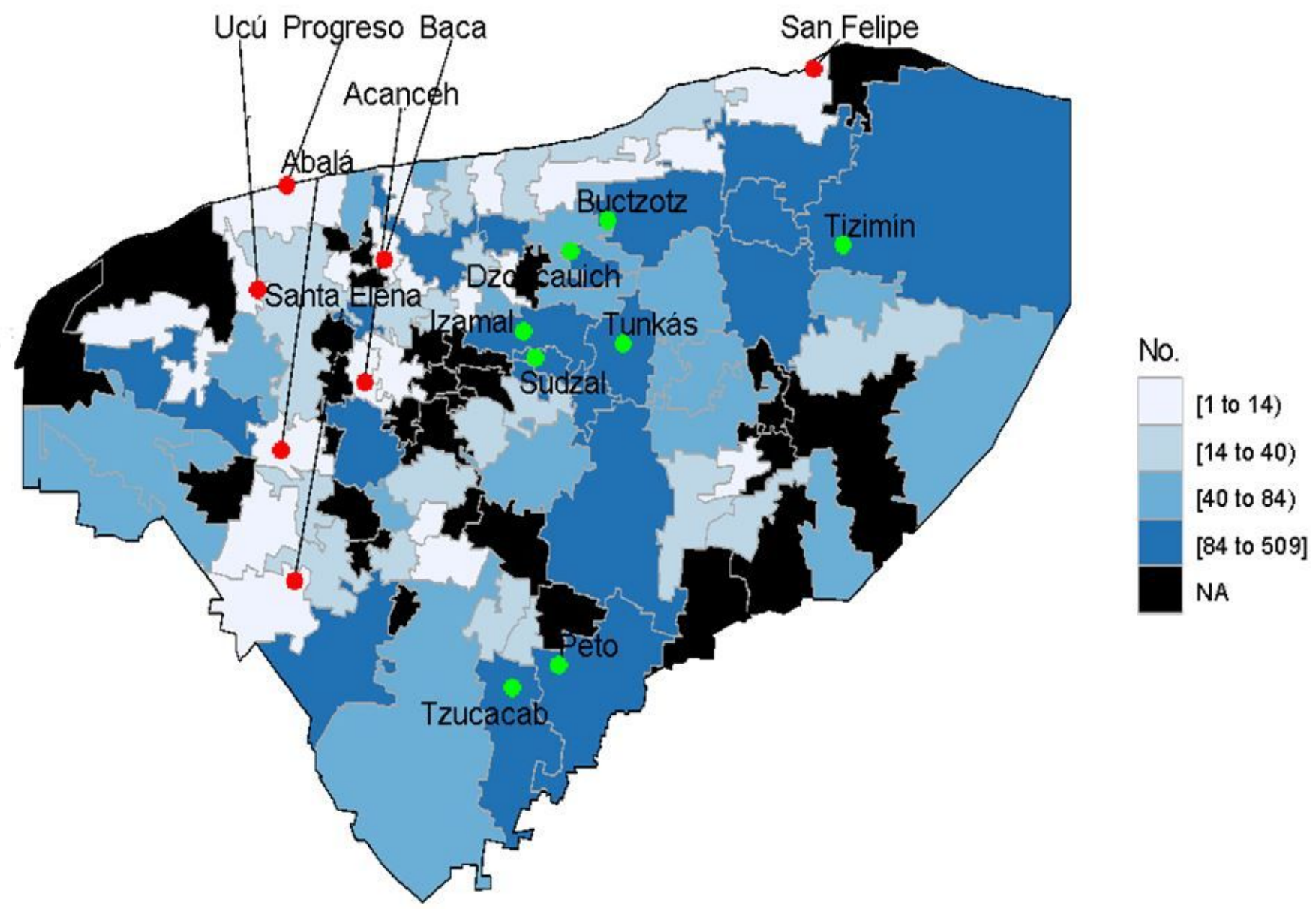

Figure 2

Number of cattle attacked in Yucatán by municipality from 2014 to 2017. Municipalities with greater number of cattle attacked are marked with green dots. Municipalities with smaller number of cattle attacked, are marked with red. NA: Municipalities where no cattle were inspected.
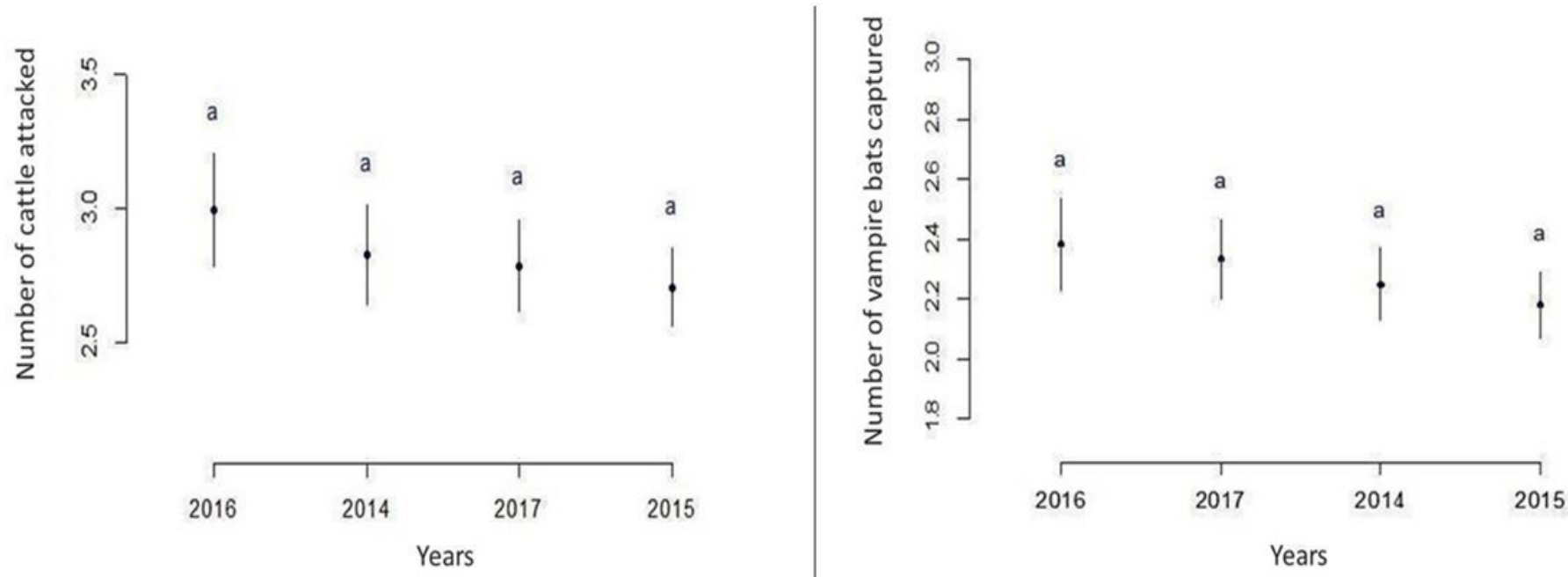


\section{Figure 3}

Yearly mean comparison for "Number of cattle attacked" and "Number of vampire bats captured."

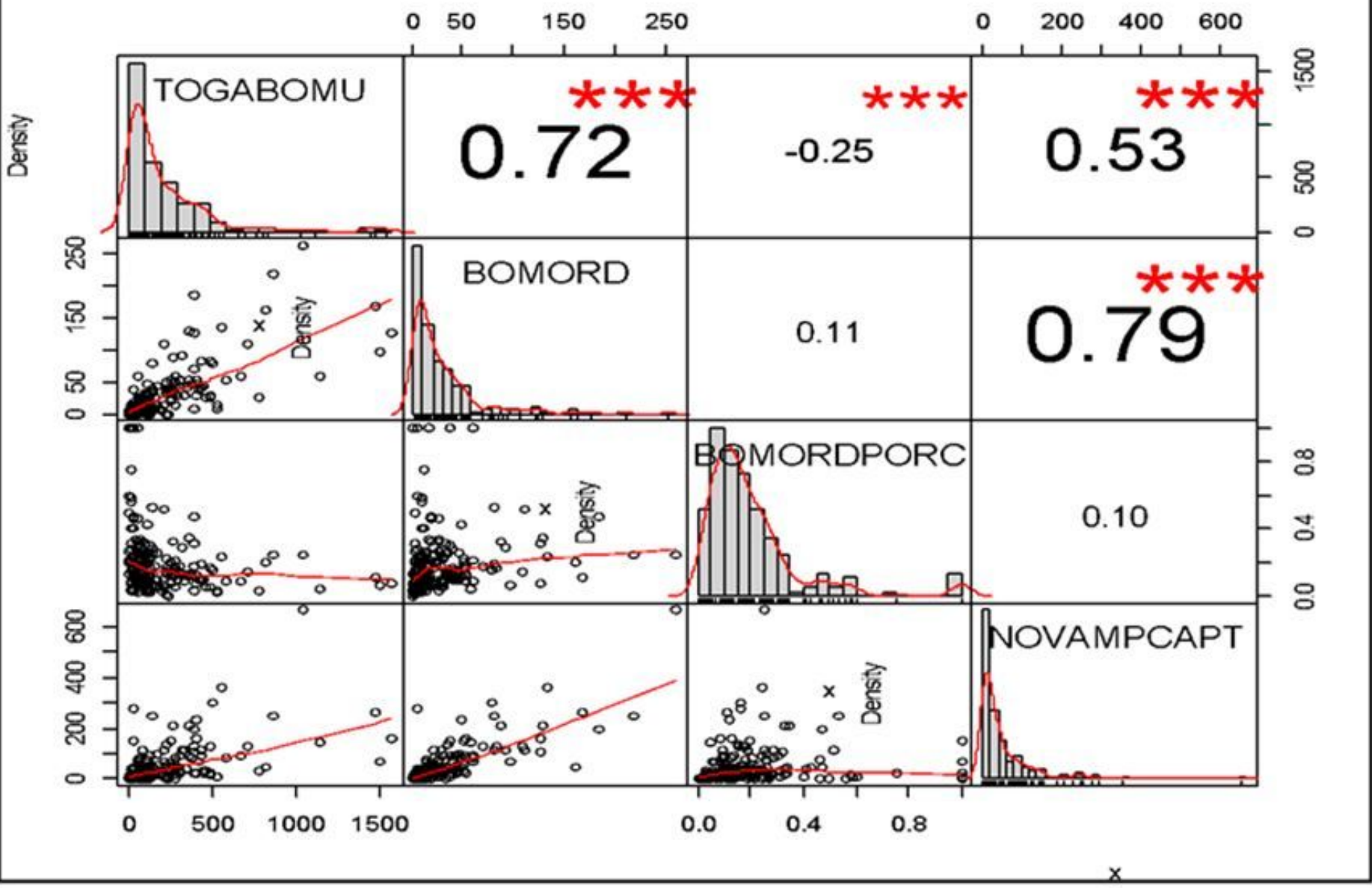

Figure 4

Pearson correlation Matrix for TOGABOMU (Total cattle per municipality) BOMORD (Cattle attacked) BOMORPORC (Proportion of cattle attacked) and NOVAMPCAPT (Number of vampire bats captured). 